У Kirjan paikka kulttuurisivulla

Tabloidisaatio ja Helsingin Sanomien

kirjallisuusjournalismin muutos 2011-

2016

Voitto Ruohonen \& Heikki Hellman 
K ulttuurisivuilla on Suomessa ollut ratkaiseva merkitys legitiimin kulttuurin määrittelijänä. Viime vuosina kulttuurijournalismia on kuitenkin arvosteltu kritiikin pinnallistumisesta. Kirjallisuudentutkija Kuisma Korhosen (2012, 62) mukaan kirja-arviot ovat lyhentyneet ja yksinkertaistuneet, koska "kriitikon pitää sanoa sanottavansa yhä lyhyemmässä tilassa ja mielellään mahdollisimman selkokielisenä, helposti kulutettavassa muodossa", ja "kirjailijan kasvonpiirteet ovat päivälehden taitosta vastaavan mukaan ilmeisesti kirjan sisältöä suurempi uutinen”. Hän arvioi kirjallisuuden osuuden kulttuuriosastoilla pienentyneen uusien taiteen- ja kulttuurinlajien myötä ja kritiikkien muuttuneen autoesittelyjen kaltaiseksi kuluttajavalistukseksi. 2010-luvun alun näkemys pinnallistumisesta on yleisesti jaettu (esim. Kantokorpi 2013; Sevänen 2018).

Kirjallisuudentutkimuksen suunnasta esitetty huomio sopii yksiin niiden kehityskulkujen kanssa, joita mediatutkijat ovat kutsuneet kulttuurijournalismin muotojen journalistisoitumiseksi ja sisältöjen popularisoitumiseksi (Hellman \& Jaakkola 2009), sosiologit populaarikulttuurin legitimoitumiseksi ja korkeakulttuurin popularisoitumiseksi kulttuurisivuilla (Purhonen ym. 2019). Kulttuurin merkityksen kasvun ja kulttuurikäsityksen laajentumisen myötä sanomalehtien kulttuuriaineisto lisääntyi ja laajeni sisällöllisesti 2000-luvun alkuun saakka (Jaakkola 2015b; Purhonen ym. 2019; Verboord \& Janssen 2015). Kuluvan vuosikymmenen kehityksestä ei ole tutkimustietoa, vaikka lehdistön sopeutumisen digitalisoituvaan mediaympäristöön ja siirtymisen tabloidiformaattiin voi olettaa kiihdyttäneen muutospaineita.

Tässä artikkelissa tarkastelemme, miten kulttuurijournalismin journalistisoituminen ja popularisoituminen näkyvät Helsingin Sanomien kirjallisuusjournalismissa. Lehti vaihtoi aiemman broadsheet-formaattinsa puolta pienempään tabloidiin tammikuussa 2013. Tabloidi on nähty keinoksi lisätä lukijaystävällisyyttä. Uusi formaatti tehostaa sisältöjen esittämistä, muuttaa lehden kerrontatekniikkaa ja tuo sivuille selkeyttä ja lisääntyvää visuaalisuutta, mikä tukee ajatusta kompaktista ja helppokäyttöisestä lehdestä. (Reunanen 2013; Sternvik 2007.) Usein koon muutos on yhdistetty myös sisällölliseen tabloidisaatioon: median lisääntyvään kaupallisuuteen, uutisten henkilöitymiseen, visualisoitumiseen ja trivialisoitumiseen (Djupsund \& Carlson 1998; Esser 1999).

Tutkimuksemme tuo empiiristä tietoa 1) kirjallisuuden ja kirjallisuuskritiikin asemasta Helsingin Sanomien kulttuuriosastossa, 2) freelancereiden ja asiantuntijoiden määrästä kriitikkoina suhteessa lehden omaan toimitukseen, 3) kulttuuriosastossa käsitellyn kirjallisuuden genre- ja sisältöjakaumasta, 4) käsitellyn kirjallisuuden kielijakaumasta sekä 5) eri kustantajien saamasta huomiosta. Artikkelin lopussa keskustelemme myös siitä, missä määrin muut tekijät kuin tabloidiformaatti voisivat selittää havaittuja muutoksia. Tutkimuksemme perustuu syys-marraskuussa vuosina 2011 ja 2016 kootun systemaattisen aineiston sisällönanalyysiin. Keskittymistä Helsingin Sanomien kirjallisuusjour- 
nalismiin perustelemme sen asemalla maan suurimpana päivälehtenä ja mielipidevaikuttajana. Lehti on yleisesti mukana tutkittaessa kulttuurijournalismin sisältöjä ja muutoksia (esim. Hellman \& Jaakkola 2009; Hurri 1993; Jaakkola 2013 ja 2015a; Purhonen ym. 2019).

\section{Tabloidisaatio kulttuurisivuilla}

Kulttuurijournalismin muutosta pitkällä aikavälillä on tutkittu sekä Suomessa (Hurri 1993; Jaakkola 2015b) että kansainvälisesti (Purhonen ym. 2019; Verboord \& Janssen 2015). Suomessa kulttuurisivuja hallitsi 1900-luvun viimeisille vuosikymmenille asti esteettinen paradigma, taidepainotteinen lähestymistapa, joka suosi kulttuuritoimittajien vahvaa erikoistumista, tavoitteli taiteesta kiinnostunutta lukijakuntaa ja piti laatua keskeisenä uutiskriteerinä. Vuosituhannen vaihdetta lähestyttäessä vallitsevaksi tuli esteettisen sijasta yleisöpainotteinen journalistinen paradigma, joka nostaa esiin yleistoimittajia, tavoittelee taiteentuntijoiden sijasta suurta yleisöä ja perustelee valintoja laadun sijasta kiinnostavuudella. (Hellman \& Jaakkola 2009.) Muutosta on selitetty mediaan ja erityisesti painettuun sanomalehteen vaikuttaneilla yleisillä taloudellisilla, teknisillä ja kulttuurisilla tekijöillä.

Lukijapainotteisella lähestymistavalla on ainakin kaksi seurausta. Ensinnäkin kulttuurijournalismin muodot ovat journalistisoituneet, minkä seurauksena julkisuus on aiempaa valikoivampaa ja kritiikin on havaittu enenevästi korvautuneen henkilökeskeisillä juttutyypeillä, kuten haastatteluilla (Jaakkola 2015a; Verboord \& Janssen 2015). Toinen seuraus on sisältöjen popularisoituminen, joka ilmenee siinä, että yhä suurempi osa kulttuurisivujen tarjonnasta keskittyy populaarikulttuuriin perinteisen korkeakulttuurin sijasta (Jaakkola 2015b; Purhonen ym. 2019; Verboord \& Janssen 2015), ja se laajenee kattamaan kulutukseen ja vapaa-aikaan liittyviä elämänalueita.

Sosiologi Semi Purhosen kansainvälinen tutkijaryhmä tiivistää kulttuurijournalismin muutoksen kahteen samanaikaiseen, ristikkäiseen kehityskulkuun, jotka ilmentävät perinteisten kulttuuristen hierarkioiden purkautumista. Yhtäältä populaarikulttuurin käsittely kulttuurisivuilla on legitimoitunut, ja toisaalta korkeakulttuurin käsittely popularisoitunut. (Purhonen ym. 2019, 61-94; 184-94.) Edellinen kehityssuunta viittaa sisältöjen popularisoitumiseen, jälkimmäinen käsittelytapojen journalistisoitumiseen. Yhä useammat kulttuurin populaarit alueet nousevat kulttuurisivujen seurantaan samalla, kun korkeakulttuurin elitistisiä aloja popularisoidaan tuomalla niiden käsittelyyn uusia, mahdollisimman lukijaystävällisiä journalistisia keinoja.

Tabloidikokoon siirtyminen näyttäisi vahvistavan kulttuurijournalismin muodoissa ja sisällöissä havaittuja muutoksia. Tabloidi muuttaa lehden rakennetta ja sisältöä, toimituksen käytännön työtä sekä lehden lukemistapaa. Pyrkimys lukijaystävälliseen, aiempaa kompaktimpaan lehteen suosii ennakoivaa 
taittoa ja mittaan kirjoittamista, vaikuttaa juttujen pituuteen ja kuvien kokoon sekä korostaa populaareja aiheita ja käsittelytapoja (Andersson 2013; Sternvik 2007; Uribe \& Gunter 2004). Vaikka tabloidiin siirtyneet päivälehdet ovat yrittäneet välttää sisältöjensä tabloidisoitumista (Reunanen ym. 2013, 73), juttujen lisääntynyt henkilöivyys ja kuvallisuus vievät päivälehtiä "iltapäivälehtimäiseen suuntaan" (Reunanen 2013, 39). Onkin katsottu, että "tabloidikoko jo itsessään ohjaa tekemään iltapäivälehtimäisen iskeviä ja lyhyitä otsikoita, käyttämään suuria pääkuvia ja merkkimäärältään kompaktimpia uutisia” (Kivioja 2018, 85).

Vaikka sisältöjen tabloidisoitumista voi yleisen kaupallistumispaineen johdosta ilmetä myös formaatista riippumatta (Andersson 2013; Djupsund \& Carlson 1998; Esser 1999), oletamme aiemman tutkimuksen perusteella, että tabloidiformaattiin siirtyminen johtaa muutoksiin journalismin 1) muotojen, 2) sisällöllisten painotusten sekä 3) puhuttelutavan tasolla. Miten tabloidisaatio ilmenee kulttuurisivuilla ja kirjallisuusjournalismissa, ei ole aiemmin juuri tutkittu (vrt. Reunanen 2013; Hellman \& Ruohonen 2019).

Muotojen osalta on esitetty tabloidin johtavan tekstien supistumiseen ja juttujen muuttumiseen visuaalisemmiksi. Mittareina on käytetty tekstien pituutta, kuvien määrää ja kokoa sekä tekstin ja kuvan määrällistä suhdetta lehden sivuilla (Anderson 2013, 12-14; Djupsund \& Carlson 1998, 105-06; McLachlan \& Golding 2000, 79-82; Uribe \& Gunter 2004, 383-87). Mekin turvaudumme konkreettisiin, juttujen ulkoisia ominaisuuksia kuvaaviin mittareihin: niiden pituuteen palstariveinä sekä kuvien määrään ja palstaleveyksiin. Kiinnitämme huomiota kirja-arvioihin, koska niiden on kriisipuheissa sanottu kärsineen. Tutkimme, miten eri kirjoittajaryhmien (freelancerit, lehden oman toimittajat, asiantuntijat) suhteet ovat kehittyneet. Oletamme tekstien lyhentyneen ja kuvituksen lisääntyneen, ja lehden suosivan omia toimittajia freelancereiden ja asiantuntijoiden kustannuksella.

Sisällöllisillä painotuksilla tarkoitetaan tiettyjen aihepiirien joko korostunutta tai vähäistä osuutta mediassa. Tällöin on tarkasteltu yhtäältä kovien politiikkaa, taloutta tai ulkomaita koskevien juttujen, toisaalta pehmeiden, kuten viihteen, human interest-, sensaatio-, rikos- sekä onnettomuusaiheiden osuutta lehden sisällössä (Andersson 2013, 14-15; Djupsund \& Carlson 1998, 104-05; McLachlan \& Golding 2000, 78-79 ja 85-87; Uribe \& Gunter 2004, 391-93). Kulttuurisivuilla sisällöllisillä painotuksilla on tarkoitettu eri taiteenlajien määrällistä osuutta sisällöstä (Hellman \& Ruohonen 2019; Purhonen ym. 2019). Me analysoimme kirjallisuuden eri lajien ja eri kielisten teosten sekä kustantajien läsnäoloa kulttuurisivuilla. Oletamme, että kirjallisuusjutuissa käsiteltäisiin tabloidin myötä aiempaa enemmän kaanonkirjallisuuden sijasta populaariksi miellettyä kirjallisuutta, ja kotimaisen kirjallisuuden osuus suhteessa käännöskirjallisuuteen olisi vahvistumassa sekä suurten kustantajien kirjallisuuden saavan osakseen kasvavaa huomiota.

Kulttuurijournalismin analyysissa puhuttelutavoilla on viitattu esimerkiksi juttutyyppeihin (Hellman \& Ruohonen 2019). Puhuttelutapa on myös lähellä 
tyyliä, jota ilmaisevina tekijöinä on tutkittu mediatekstien henkilöitymistä ja intiimistymistä, keskittymistä yksityiselämään julkisen tai ammatillisen roolin sijasta (Andersson 2013, 15-16; Uribe \& Gunter 2004, 397). Me tutkimme, ovatko kirjailijan persoona ja yksityinen elämä tabloidin myötä enenevästi esillä $\mathrm{Hel}$ singin Sanomien kirjallisuusjournalismissa. Sen selvittämiseksi lähiluemme kulttuuriosaston avauksena olevia kirjailijahaastatteluja.

Edellä kuvattuja sanomalehden muotoon, sisältöön ja ilmaisukeinoihin liittyviä oletettuja muutoksia kutsumme tabloidisaatiohypoteesiksi.

\section{Empiiriset aineistot ja niiden käsittely}

Aineistonamme ovat Helsingin Sanomien kulttuurisivut syys-marraskuulta vuosina 2011 ja 2016. Tarkasteluvuodet on valittu ennen ja jälkeen lehden siirtymistä tabloidiksi tammikuussa 2013. Aineisto on kerätty systemaattisesti. Jokaiselta lehden ilmestymispäivältä on laskettu painetun lehden kulttuurisivujen laajuus ja kulttuurisivujen juttujen kokonaismäärä. Tarkemmin on koodattu kirjallisuutta käsittelevät jutut. Päämetodi on määrällinen sisällönanalyysi. Lisäksi aineistosta on tehty laadullisia havaintoja. Tarkastelujaksolla ilmestyneitä kahta kirjamessuliitettä emme niiden muista lehden numeroista poikkeavan erityislaadun vuoksi käsittele. ${ }^{1}$

Kokonaisaineisto on 178 Helsingin Sanomien kulttuuriosastoa, 89 osastoa kummaltakin vuodelta. Aineiston koostumus ja valintatapa erottavat analyysimme aiemmista, joissa on tutkittu pitkiä ajanjaksoja ja poimittu niiltä yksittäisiä lehtiä tarkemman analyysin kohteeksi (esim. Hurri 1993; Jaakkola 2013). Mikään tapa ottaa näyte ei sulje pois eri aihepiirien journalistisessa käsittelyssä ilmenevää sekä sesonkiluonteista että satunnaista vaihtelua. Kulttuuriosaston sisällä eri aiheet vaihtelevat päivästä toiseen. Oletamme kolmen kuukauden luonnollisen jakson antavan konstruoitua aineistoa paremman käsityksen kirjallisuuden asemasta kulttuurisivuilla.

Aineistossa on kaikkiaan 2715 kulttuurisivujen juttua. Tarkempi tutkimusaineisto koostuu 614 kirjallisuusaiheisesta jutusta, joista 351 (57,2 \%) ilmestyi syksyllä 2011 ja 263 (42,8 \%) 2016. Aineisto koottiin Excel-laskentataulukkoon, jossa havaintoyksikkönä on yksittäinen juttu. Jokaisesta jutusta koodattiin julkaisupäivä, otsikko, kirjoittaja, kirjoittajan status (oma toimittaja, freelancer, ulkopuolinen asiantuntija), juttutyyppi (arvio, kolumni tai kommentti, essee, suositus, mielipidekirjoitus, fiktio, uutinen, haastattelu, feature, muu kirjoitus), jutun pituus riveissä ja jutun asema kulttuurisivuilla (osaston lähtöjuttu vai ei).

Edelleen koodasimme, edustaako jutun käsittelemä kirja kauno-, tieto- vai muuta kirjallisuutta. Muu kirjallisuus -luokkaan sijoitimme lasten- ja sarjakuvakirjat. Kirjasimme jutun käsittelemän kirjailijan ja kirjan nimen, kustantajan, kirjallisuudenlajin, kaunokirjallisuudesta kirjan lajityypin sekä tietokirjallisuudesta aihepiirin, kirjan alkuperäiskielen ja kirjoittajan sukupuolen. Lisäksi koo- 
dasimme kuvien määrät ja palstaleveydet sekä erikseen kirjailijoita esittävien kuvien määrät ja palstaleveydet. ${ }^{2}$

Helsingin Sanomien kirjallisuusjournalismi vuosina 2011 ja 2016

\section{Kirjallisuusjuttujen määrä}

Tabloidiformaatti muuttaa sanomalehden osastojakoa (Reunanen 2013, 12-13), joskin kulttuurisivujen sijainti on vaihdellut formaatista riippumatta (Heikkilä ym. 2018, 678-80). ${ }^{3}$ Tabloidikoon yleistyessä ja sanomalehtien taiton muuttuessa visuaalisemmaksi lukijoille tarjottujen juttujen määrä on laskenut (Honkonen 2013). Mediatutkija Esa Reunasen (2013) tutkimuksessa ei vielä havaittu Helsingin Sanomien juttumäärän ja -alan vähentyneen formaattimuutoksen myötä, vaikka lehden sivumäärä broadsheet-sivuiksi muutettuna laski. Pidemmän aikavälin aineistossa juttujen väheneminen oli nähtävissä. Helsingin Sanomien kulttuurisivuilla oli vuonna 2011 keskimäärin 17,9 juttua numeroa kohden, vuonna 2016 enää 12,7 juttua. Juttujen kokonaismäärä supistui runsaalla neljänneksellä viidessä vuodessa. (Taulukko 1.)

Taulukko 1. Kulttuuriosaston jutut ja kirjallisuusjutut syys-marraskuussa 2011 ja 2016

\begin{tabular}{|l|cc|c|}
\hline Tunnusluku & $\mathbf{2 0 1 1}$ & $\mathbf{2 0 1 6}$ & Muutos \\
\hline Kulttuurisivuja keskimäärin* & 2,6 & 2,8 & $+7,7 \%$ \\
\hline Juttuja yhteensä & 1589 & 1126 & $-29,1 \%$ \\
\hline Kirjallisuusjuttuja yhteensä & 351 & 263 & $-25,1 \%$ \\
\hline Kirjallisuusjuttujen osuus (\%) & 22 & 23,4 & $+6,4 \%$ \\
\hline Kirjallisuusaiheisia lähtöjuttuja yhteensä & 20 & 28 & $+40,0 \%$ \\
\hline Kirjallisuusaiheisten lähtöjuttujen osuus (\%) & 22,5 & 31,5 & $+40,0 \%$ \\
\hline
\end{tabular}

*Ilmoitukset pois lukien. Vuoden 2016 sivumäärä muunnettu broadsheet-sivuiksi.

Vaikka kirjallisuutta käsittelevien juttujenkin määrä väheni neljänneksellä, niiden suhteellinen osuus kulttuurisivujen tarjonnasta kasvoi hiukan, 22 prosentista runsaaseen 23 prosenttiin. Osuus ei poikkea Hurrin $(1993,347)$ esittämästä 1950-1970-lukujen määrästä, ja se on linjassa myös Jaakkolan (2013 ja 2015a) tulosten kanssa. 2000-luvun alkuvuosina lehden kulttuuriosaston laajuus asettui 2,5 broadsheet-sivun tasolle (Hellman \& Jaakkola 2009, 31). Syksyllä 2011 kulttuuria oli keskimäärin 2,6 sivua ja syksyllä 2016 tabloidisivut broadsheetsivuiksi muunnettuna 2,8 sivua päivässä, joten osasto oli aavistuksen verran kasvanut.

Aineiston perusteella kulttuuriosasto on säilyttänyt tabloidimuutoksessa asemansa osana Helsingin Sanomien kokonaissisältöä, kun lehden kokonaissivumäärä tabloidiin siirtymisen myötä supistui noin viidenneksellä (Hell- 
man \& Ruohonen 2019, 224). Kirjallisuuden aseman vahvistumisesta osaston sisällä kertovat juttujen suhteellisen osuuden nousu sekä kirjallisuusaiheisten lähtöjuttujen lisääntyminen. Vaikka kilpailu palstatilasta on uusien taidemuotojen myötä kiristynyt (Jaakkola 2013; Korhonen 2012; Purhonen ym. 2019), aineistomme ei tue pelkoa kirjallisuuden aseman heikkenemisestä. Tosiasia kuitenkin on kirjallisuusjuttujen, kuten kaikkien muidenkin kulttuurijuttujen, absoluuttisen määrän lasku tabloidiin siirtymisen jälkeen.

Odotettua olisi ollut, että henkilökeskeiset ja lukijaystävälliset juttutyypit, kuten haastattelut, kolumnit ja feature-jutut olisivat lisääntyneet arvioiden kustannuksella. Aineisto ei vahvista oletusta. Taulukon 2 mukaan uutisten osuus oli tarkastelujaksolla supistunut, feature-juttujen ja haastattelujen osuus taas kasvanut, mutta kuitenkin vähemmän kuin tabloidisaatiohypoteesi antaisi odottaa. Arvottavista juttutyypeistä osuuttaan vuodesta 2011 vuoteen 2016 lisäsivät kirja-arviot, esseet ja suositukset, sitä menettivät kolumnit ja kommentit. Mielipidekirjoitukset ja fiktiiviset kirjoitukset katosivat kokonaan kulttuurisivuilta. Absoluuttisesti lisääntyivät vain esseet ja suositukset. Pääosin muutokset olivat vähäisiä. Ne eivät epäsuorastikaan vahvista oletusta sisällöllisestä tabloidisaatiosta. Säännöllisten lauantaiesseiden vakiintuminen ja kritiikkien osuuden lievä kasvu todistavat jopa päinvastaisesta.

Taulukko 2. Kirjallisuusjutut juttutyypeittäin syys-marraskuussa 2011 ja 2016

\begin{tabular}{|l|ccc|cc|}
\hline \multirow{2}{*}{ Juttutyyppi } & \multicolumn{3}{|c|}{ Juttujen määrä } & \multicolumn{2}{c|}{ Juttutyypin osuus \% } \\
\cline { 2 - 6 } & $\mathbf{2 0 1 1}$ & $\mathbf{2 0 1 6}$ & Muutos & $\mathbf{2 0 1 1}$ & $\mathbf{2 0 1 6}$ \\
\hline Arvio & 126 & 99 & $-21,4 \%$ & 35,9 & 37,6 \\
Kolumni tai kommentti & 29 & 16 & $-44,8 \%$ & 8,3 & 6,1 \\
Essee & 2 & 10 & $+400,0 \%$ & 0,6 & 3,8 \\
Suositus & 10 & 16 & $+60,0 \%$ & 2,8 & 6,1 \\
Mielipide & 6 & 0 & $-100,0 \%$ & 1,7 & 0,0 \\
Fiktio & 6 & 0 & $-100,0 \%$ & 1,7 & 0,0 \\
Uutinen & 85 & 58 & $-31,8 \%$ & 24,2 & 22,1 \\
Haastattelu & 26 & 21 & $-19,2 \%$ & 7,4 & 8,0 \\
Feature & 15 & 15 & $\pm 0,0 \%$ & 4,3 & 5,7 \\
Muu & 46 & 28 & $-39,1 \%$ & 13,1 & 10,6 \\
Yhteensä & $\mathbf{2 5 1}$ & $\mathbf{2 6 3}$ & $\mathbf{- 2 5 , 1} \%$ & $\mathbf{1 0 0 , 0}$ & $\mathbf{1 0 0 , 0}$ \\
\hline
\end{tabular}

Muoto: juttujen pituus, kuvitus ja tekijät

Aineiston yleispiirteiden kuvauksen jälkeen tarkastelemme tabloidisaation eri ulottuvuuksia ja aloitamme muotoseikoista: kirjallisuusjuttujen pituudesta, kuvituksesta ja tekijöistä. Vaikka tabloidi mahdollistaa aiempaa pidempien juttujen julkaisemisen (Hellman \& Ruohonen 2019, 224-25), oletus oli, että kir- 
jallisuusaiheiset jutut olisivat lyhentyneet. Taulukon 3 tulokset osoittavat, että vastoin odotuksia kirjallisuusjutut kasvoivat rivimäärältään tarkastelujakson aikana yli kolmanneksella. Erityisesti pidentyivät haastattelut, feature-jutut ja esseet. Arvostelujen keskimitta kasvoi, ja niiden keskipituuden kasvu 15 prosentilla on merkittävä. Tabloidisaatiohypoteesin kannalta tulokset ovat ristiriitaiset; haastattelujen ja feature-juttujen ohella myös kirja-arviot ja esseet pidentyivät.

Taulukko 3. Kirjallisuusjuttujen keskipituus juttutyypeittäin syys-marraskuussa 2011 ja 2016

\begin{tabular}{|l|cc|c|}
\hline \multirow{2}{*}{ Juttutyyppi } & \multicolumn{3}{|c|}{ Keskipituus (riviä) } \\
\cline { 2 - 4 } Arvio & $\mathbf{2 0 1 1}$ & $\mathbf{2 0 1 6}$ & Muutos \\
Kolumni tai kommentti & 96,8 & 111,8 & $+15,5 \%$ \\
Essee & 73,9 & 75,4 & $+2,0 \%$ \\
Suositus & 180,0 & 279,4 & $+55,2 \%$ \\
Mielipide & 24,6 & 26,4 & $+7,3 \%$ \\
Fiktio & 47,0 & 0,0 & $-100,0 \%$ \\
Uutinen & 72,7 & 0,0 & $-100,0 \%$ \\
Haastattelu & 36,7 & 48,7 & $+32,7 \%$ \\
Feature & 134,8 & 212,8 & $+57,9 \%$ \\
Muu & 143,2 & 211,1 & $+47,4 \%$ \\
Keskipituus (riviä) & 26,3 & 20,8 & $-20,9 \%$ \\
\hline N (rivejäyhteensä) & $\mathbf{7 3 , 6}$ & $\mathbf{1 0 0 , 9}$ & $+\mathbf{3 7 , 1} \%$ \\
\hline
\end{tabular}

Merkittävää on, että lyhyiden, alle 50 rivin pituisten arvioiden määrä putosi 25 prosentista viiteen prosenttiin, mutta keskipitkien 101-200 rivin arvioiden määrä nousi 38 prosentista 51 prosenttiin. Vuonna 2016 julkaistiin jo muutama yli 300 rivin arvio, kun vuonna 2011 sellaisia ei ollut lainkaan. (Hellman \& Ruohonen 2019, 227-28.) 2010-luvun alun huoli kirja-arvioiden lyhyydestä ja epäanalyyttisyydestä ei ole ollut täysin aiheetonta. Vastoin tabloisaatiohypoteesin mukaista oletusta pienempi formaatti näytti korjanneen tilannetta, sillä hyvin lyhyet arviot lähes katosivat.

Kirjallisuusaiheisten juttujen kuvituksen kehitys näytti sen sijaan noudattavan oletusta. Tabloidiin siirtyminen rohkaisi kuvien aiempaa runsaampaan käyttöön. Syksyllä 2011 kuvia oli keskimäärin 0,8 juttua kohden, syksyllä 2016 määrä oli kasvanut 1,2 kuvaan. Absoluuttisestikin kuvia julkaistiin vuonna 2016 enemmän kuin viisi vuotta aiemmin, vaikka juttujen määrä oli vähentynyt. Syksyllä 2016 kuvattomia kritiikkejä oli enää seitsemän prosenttia, kun viisi vuotta aiemmin vailla kuvaa oli vielä enemmän kuin joka neljäs kirja-arvio (28,0 \%). Kuvien palstaleveydet eivät olleet muuttuneet, mutta puolittuneen sivukoon 
myötä kuvien osuus painopinnasta oli kasvanut. (Ks. myös Hellman \& Ruohonen 2019, 228-29.)

Koska kriisipuheessa on erityisesti kannettu huolta kritiikin asemasta ja asiantuntemuksesta, analysoimme Helsingin Sanomien kriitikkokunnan jakaumaa. Taulukko 4 osoittaa, että kaikista kirja-arvioista lehden omat toimittajat kirjoittivat molempina vuosina runsaan kolmanneksen, freelancerien osuus kasvoi runsaasta kolmanneksesta yli puoleen ja asiantuntijoiden laski runsaasta neljänneksestä vajaaseen kymmeneen prosenttiin. Kaunokirjallisuutta koskevien arvioiden kohdalla lehden omien toimittajien osuus kriitikoista laski syksystä 2011 syksyyn 2016 selvästi, kun taas freelancereiden osuus kaksinkertaistui ja asiantuntijoiksi laskettavien kriitikoiden, kuten lehden ulkopuolisten kirjallisuudentutkijoiden, osuus romahti. Tietokirjallisuuden kohdalla kehityssuunta asiantuntijoiden käytössä oli sama, kun taas lehden omien toimittajien panos yli kolminkertaistui.

Taulukko 4. Kirja-arviot kriitikon aseman mukaan syys-marraskuussa 2011 ja 2016 (\%)

\begin{tabular}{|l|cc|cc|cc|}
\hline \multirow{2}{*}{ Kirjallisuudenlaji } & \multicolumn{2}{|c|}{ Oma toimittaja } & \multicolumn{2}{|c|}{ Freelancer } & \multicolumn{2}{c|}{ Asiantuntija } \\
\cline { 2 - 7 } & $\mathbf{2 0 1 1}$ & $\mathbf{2 0 1 6}$ & $\mathbf{2 0 1 1}$ & $\mathbf{2 0 1 6}$ & $\mathbf{2 0 1 1}$ & $\mathbf{2 0 1 6}$ \\
\hline Kaunokirjallisuus & $\mathbf{4 2 , 2}$ & $\mathbf{2 7 , 9}$ & 37,8 & $\mathbf{7 0 , 5}$ & $\mathbf{2 0 , 0}$ & $\mathbf{1 , 6}$ \\
Tietokirjallisuus & 14,3 & 51,4 & 33,3 & 31,4 & 52,4 & 17,1 \\
Muu kirjallisuus & $\mathbf{1 3 , 3}$ & 0,0 & 46,7 & 33,3 & 40,0 & $\mathbf{6 6 , 7}$ \\
Yhteensä & $\mathbf{3 4 , 1}$ & $\mathbf{3 5 , 4}$ & $\mathbf{3 8 , 1}$ & $\mathbf{5 5 , 6}$ & $\mathbf{2 7 , 8}$ & $\mathbf{9 , 1}$ \\
\hline Arvioita (N) & $\mathbf{4 3}$ & $\mathbf{3 5}$ & $\mathbf{4 8}$ & $\mathbf{5 5}$ & $\mathbf{3 5}$ & $\mathbf{9}$ \\
\hline
\end{tabular}

Luvut kertovat kaunokirjallisuuden arvostelujen enenevästä ulkoistamisesta freelancereille (Jaakkola 2013, 38-39; 2015a, 393-95) ja tietokirjallisuuden kritiikin ottamisesta toimituksen käsiin. Havainto tukee kirjallisen kentän esittämää huolta kritiikin muuttuneesta luonteesta ja asiantuntemuksen aliarvostuksesta.

Kriitikon sukupuolen mukaan tarkasteltuna miesten osuus kaunokirjallisuuden arvioijina vahvistui jonkin verran, 62 prosentista 70 prosenttiin, ja naisten osuus heikkeni. Kaikki tietokirja-arviot vuonna 2011 olivat miesten kirjoittamia, ja viisi vuotta myöhemminkin 86-prosenttisesti. Keskimäärin kaksi kolmasosaa, syksyllä 2016 jopa kolme neljäsosaa kaikista kritiikeistä oli miesten kirjoittamia. Se vastaa Jaakkolan (2013, 41-42) havaintoa, jonka mukaan kaksi kolmasosaa viiden johtavan suomalaislehden kirjallisuuskritiikeistä vuosina 1978-2008 oli miesten laatimia.

\section{Sisällölliset painotukset: kirjat, kirjailijatja kustantajat}

Seuraavaksi analysoimme kirja-arvioita kirjallisuuden lajin, kirjailijan sukupuolen, alkuperäiskielen ja kirjojen kustantajien mukaan. Nämä tekijät ilmentävät kirjallisuusjournalismin sisällöllisiä painotuksia. Taulukon 5 mukaan arvioiden kokonaismäärä laski tarkastelujaksolla viidenneksellä, tietokirjallisuuden 
osuus arvioiduista kirjoista kaksinkertaistui, kaunokirjallisuuden arvioiden osuus laski hiukan, ja muu kirjallisuus -lohkoon luokittelemamme lasten- ja sarjakuvakirjat katosivat arvostelupalstoilta lähes kokonaan. Absoluuttisina lukuina tarkasteltuna kaunokirjallisuutta käsittelevien arvioiden määrä laski kolmanneksella, kun taas tietokirja-arviot lisääntyivät puolella.

Taulukko 5. Kirja-arviot kirjallisuudenlajin mukaan syys-marraskuussa 2011 ja 2016

\begin{tabular}{|l|cc|cc|cc|}
\hline \multirow{2}{*}{ Kirjallisuudenlaji } & \multicolumn{2}{|c|}{ Arvioita kaikkiaan } & \multicolumn{2}{c|}{ Osuus arvioista (\%) } & \multicolumn{2}{c|}{ Arvioituja kirjoja } \\
\cline { 2 - 8 } & $\mathbf{2 0 1 1}$ & $\mathbf{2 0 1 6}$ & $\mathbf{2 0 1 1}$ & $\mathbf{2 0 1 6}$ & $\mathbf{2 0 1 1}$ & $\mathbf{2 0 1 6}$ \\
\hline Kaunokirjallisuus & 90 & 61 & 71,4 & 61,6 & 89 & 62 \\
Tietokirjallisuus & 21 & 35 & 16,7 & 35,4 & 23 & 38 \\
Muu kirjallisuus & 15 & 3 & 11,9 & 3 & 15 & 3 \\
Yhteensä & $\mathbf{1 2 6}$ & $\mathbf{9 9}$ & $\mathbf{1 0 0}$ & $\mathbf{1 0 0}$ & $\mathbf{1 2 7}$ & $\mathbf{1 0 3}$ \\
\hline
\end{tabular}

Tabloidisaatiohypoteesin mukaista olisi, jos arvioitu kaunokirjallisuus edustaisi enenevästi populaareja lajityyppejä, jollaisiksi voitaisiin lukea johonkin vakiintuneeseen kirjalliseen genreen (rikoskirjallisuus, fantasiakirjallisuus, tieteiskirjallisuus jne.) kuuluvat teokset, ja tietokirjallisuudessa huomiota saisivat populaarit aihepiirit. Samoin popularisoitumista ilmentäisi, jos korkeakirjallisiksi koetut runous ja novellit olisivat menettäneet asemiaan arvioinneissa, samoin vaativa, ei-populaari tietokirjallisuus.

Koska pidämme kirjallisuuden jonkin lajin tai alueen määrittelyä populaariksi (vrt. Purhonen ym. 2019, 41-42) ongelmallisena, viittaamme käsitteellä kuluttajien eniten suosimaan kirjallisuuteen. Nojaamme kaunokirjallisuuden osalta perinteisiin päägenreihin (romaanikirjallisuus, novellikirjallisuus, lyriikka, esseekirjallisuus, lastenkirjallisuus, nuortenkirjallisuus). Arvioitua tietokirjallisuutta kuvaamme aihepiireittäin (uskonto ja filosofia, yhteiskunta ja politiikka, historia, taiteet, luonto, harrasteet), ja muuhun kirjallisuuteen luemme lasten- ja sarjakuvakirjat.

Kuten taulukko 6 osoittaa, romaanikirjallisuus muodostaa noin puolet arvioiduista kirjoista, eikä sen osuus ole merkittävästi muuttunut. Tulos vastaa lukijoiden odotuksia; lukemistutkimuksista (Eskola 1990) ja kirjallista makua koskevista analyyseista (Purhonen ym. 2014) tiedetään, että kaikkien suomalaisten suosikkilukemista ovat romaanit, sen sijaan lyriikkaa ja novelleja suosii kirjallinen eliitti. Arvioiden popularisoitumista tukevaa on lyriikan osuuden supistuminen.

Arvioitu tietokirjallisuus on aihejakaumaltaan kapeaa: yhteiskunta ja politiikka, historia ja taiteet hallitsevat seurantaa, filosofia ja luonto eivät pääse arvioitaviksi kulttuurisivuilla, eivät myöskään erilaiset harrastuksiin liittyvät kirjat. Jälkimmäinen viittaa siihen, että matkailukirjojen arviot ovat siirtyneet matkailusivuille, ruokakirjojen ruokasivuille, mikä vastaa Lingon (2016) havaintoja tietokirjallisuuden eriytyneestä julkisuudesta. 
Taulukko 6. Kirja-arviot kirjan genren tai aihepiirin mukaan syys-marraskuussa 2011 ja 2016

\begin{tabular}{|c|c|c|c|c|}
\hline \multirow{2}{*}{ Kirjan genre tai aihepiiri } & \multicolumn{2}{|c|}{ Arvioituja kirjoja (N) } & \multicolumn{2}{|c|}{$\begin{array}{c}\text { Osuus arvioiduista kirjoista } \\
\text { (\%) }\end{array}$} \\
\hline & 2011 & 2016 & 2011 & 2016 \\
\hline \multicolumn{5}{|l|}{ Kaunokirjallisuus } \\
\hline Romaanikirjallisuus & 60 & 50 & 47,2 & 48,5 \\
\hline Novellikirjallisuus & 7 & 5 & 5,5 & 4,9 \\
\hline Lyriikka & 12 & 5 & 9,4 & 4,9 \\
\hline Esseekirjallisuus & 2 & o & 1,6 & 0,0 \\
\hline Nuortenkirjallisuus & 8 & 2 & 6,3 & 1,9 \\
\hline \multicolumn{5}{|l|}{ Tietokirjallisuus } \\
\hline Uskonto, filosofia & 0 & 0 & 0,0 & 0,0 \\
\hline Yhteiskunta, politiikka & 12 & 11 & 9,4 & 10,7 \\
\hline Historia & 7 & 6 & 5,5 & 5,8 \\
\hline Taiteet & 4 & 21 & 3,1 & 20,4 \\
\hline Luonto & 0 & 0 & 0,0 & 0,0 \\
\hline Harrasteet & 0 & 0 & 0,0 & 0,0 \\
\hline \multicolumn{5}{|l|}{ Muи kirjallisuus } \\
\hline Lastenkirjallisuus & 13 & 2 & 10,2 & 1,9 \\
\hline Sarjakuvakirjallisuus & 2 & 1 & 1,6 & 1,0 \\
\hline Yhteensä & 127 & 103 & 100,0 & 100,0 \\
\hline
\end{tabular}

Purhosen tutkijaryhmän mukaan vain pieni osa Helsingin Sanomien kaunokirjallisuutta käsittelevistä jutuista on 1960-luvulta alkaen käsitellyt niin sanottua genrekirjallisuutta (Purhonen ym. 2019, 42-43). Me lähestyimme genrekirjallisuutta toisin ja erotimme romaanikirjallisuudesta tunnistettavia alalajeja. Niistä yleisimmäksi osoittautuivat aikalaiskirjallisuudeksi nimeämämme teokset. Siihen luokittelimme romaanit, joiden kerronta tapahtuu nykyajassa, jotka käsittelevät yksilön, ryhmän tai koko yhteiskunnan kannalta keskeisiä, ajassa kiinni olevia teemoja tai elämäntilanteita ja joita ei ole kirjoitettu selvästi mihinkään muuhun vakiintuneeseen kirjallisuuden genreen. Tällaisia romaaneja oli vuonna 2011 arvioiduista teoksista 26 (42,6\%), viisi vuotta myöhemmin $23(46,0 \%)$.

Muista genreistä näkyvimpiä olivat historialliset romaanit (18,0 vs. 14,0 \%) ja rikosromaanit (14,8 vs. 16,0 \%). Näihin kolmeen ryhmään kuului molempina tarkasteluvuosina kolme neljästä arvioidusta romaanista, eikä merkittävää muutosta ollut tapahtunut. Lisäksi aineistoon sisältyi yksittäisinä valintoina esimerkiksi autofiktioita, maaseuturomaaneja, satiireja, kauhuromaaneja, fantasiaromaaneja sekä tieteisromaaneja. 


\section{Suomenkielinen kirjallisuus muodosti koko aineistossa}

\section{kolme neljäsosaa arvioiduista kaunokirjoista, ja määrä oli}

\section{kasvava, tietokirjoissa noin 85 prosenttia.}

Tietokirja-arvioiden painottuminen taiteisiin sekä yhteiskuntaan ja politiikkaan on osin seurausta luokitteluperiaatteista. Arvioiduista teoksista etenkin taiteisiin keskittyvät olivat paria poikkeusta lukuun ottamatta elämäkertoja tai muistelmia, jotka voitaisiin yhtä lailla luokitella historiaan ja jotka molemmat lukeutuvat lukijoiden suosimiin lajityyppeihin (Purhonen ym. 2014, 73). Tietokirja-arvioiden sisällön popularisoitumisesta kertoo, että syksyllä 2016 arvioitiin peräti 11 rockmuusikoiden muistelmateosta tai elämäkertaa. Merkittävä osa yhteiskuntaa ja politiikkaa käsittelevistä teoksista oli muistelmia.

Vaikka tabloidisaatiota ja kritiikin kriisiä koskevissa keskusteluissa sukupuolinäkökulma ei ole ollut erityisesti esillä, totesimme, että kaunokirjallisuudessa mieskirjailijoiden osuus arvioiduista kirjoista kasvoi tarkastelukaudella 60 prosentista 70:een. Tietokirjallisuus oli keskimäärin vielä miesvaltaisempaa, joskin siellä mieskirjailijoiden osuus laski 87:stä 74 prosenttiin.

Kaunokirjallisuuden julkisuutta sanomalehdissä analysoineet tutkimukset ovat havainneet kotimaisen kirjallisuuden hallitsevan arvostelupalstoja. Sen näkyvyys olisi myös hypoteesin mukaista, koska monet kotimaiset kirjailijat ovat näkyvästi läsnä populaarissa julkisuudessa (Kantokorpi 2013; Ruohonen 2018b). Omassa aineistossamme kotimaisen osuus kaunokirjallisuuden arvioissa vahvistui tarkastelujaksolla ulkomaisen vastaavasti heiketessä, mikä tukee oletusta. Kun syksyllä 2011 noin 79 prosenttia arvioidusta kaunokirjallisuudesta oli kotimaista, viisi vuotta myöhemmin osuus oli kasvanut 87 prosenttiin. Vaikka tietokirjallisuudessa kotimaisen osuus laski hieman, 87:stä 84 prosenttiin, vain harvat käännöstietokirjat nousivat arvostelupalstoille.

Alkuperäkielen (taulukko 7) mukaan tarkasteltuna suomenkielinen kirjallisuus muodosti koko aineistossa noin kolme neljäsosaa arvioiduista kaunokirjoista, ja määrä oli kasvava, tietokirjoissa noin 85 prosenttia. Ruotsin kielen osuus arvioidusta kaunokirjallisuudesta oli runsaat kuusi prosenttia, tietokirjallisuuden kohdalla alle kaksi. Englanninkielisten teosten osuus kaunokirjallisuudesta laski kymmenestä prosentista kolmeen, mutta nousi tietokirjallisuudessa nollasta 13 prosenttiin. Kaikkien muiden kielten yhteinen osuus arvioiduista kirjoista oli kahdeksan prosenttia. Ranskankielisiä kirjoja löytyi aineistosta viisi, saksankielisiä neljä ja espanjankielisiä yksi. Luvut kertovat kotimaisen kirjallisuuden hallitsevuudesta ja arvioidun kirjallisuuden kapeasta kielivalikoimasta, minkä tulkitsemme tabloidisaatio-oletuksen mukaiseksi. Huomiota kiinnittää ruotsin kielen vaatimaton osuus. 
Taulukko 7. Kirja-arviot kirjan alkukielen mukaan syys-marraskuussa 2011 ja 2016 (\%)

\begin{tabular}{|l|cc|cc|cc|cc|}
\hline Alkukieli & \multicolumn{2}{|c|}{ Suomi } & \multicolumn{2}{c|}{ Ruotsi } & \multicolumn{2}{c|}{ Englanti } & \multicolumn{2}{c|}{ Muut kielet } \\
\hline Kirjallisuudenlaji & $\mathbf{2 0 1 1}$ & $\mathbf{2 0 1 6}$ & $\mathbf{2 0 1 1}$ & $\mathbf{2 0 1 6}$ & $\mathbf{2 0 1 1}$ & $\mathbf{2 0 1 6}$ & $\mathbf{2 0 1 1}$ & $\mathbf{2 0 1 6}$ \\
\hline Kaunokirjallisuus & 74,4 & 80,3 & 6,7 & 6,6 & 10 & 3,3 & 8,9 & 9,8 \\
Tietokirjallisuus & 87 & 84,2 & 4,3 & 0 & 0 & 13,2 & 8,7 & 2,6 \\
Muu kirjallisuus & 78,6 & 100 & 0 & 0 & 21,4 & 0 & 0 & 0 \\
Yhteensä & $\mathbf{7 7 , 2}$ & $\mathbf{8 1 , 6}$ & $\mathbf{5 , 5}$ & $\mathbf{3 , 9}$ & $\mathbf{9 , 4}$ & $\mathbf{6 , 8}$ & $\mathbf{7 , 9}$ & $\mathbf{7 , 8}$ \\
\hline Arvioituja kirjoja & $\mathbf{9 8}$ & $\mathbf{8 4}$ & $\mathbf{7}$ & $\mathbf{4}$ & $\mathbf{1 2}$ & $\mathbf{7}$ & $\mathbf{1 0}$ & $\mathbf{8}$ \\
\hline
\end{tabular}

Suuret kustantajat hallitsevat kirjallisella kentällä julkisuutta, koska niillä on laaja kirjailijatalli ja paljon resursseja kirjailijoidensa näkyvyyden edistämiseen. Tabloidisaation voikin olettaa suosivan suurimpia kustantajia. Oma aineistomme ei vahvista oletusta. Vaikka kahden suurimman ryhmittymän, Bonnier Kirjat Suomi Oy:n ${ }^{5}$ ja Otava-konsernin, ${ }^{6}$ teokset muodostavat yli puolet kaikista arvioiduista teoksista, niiden yhteenlaskettu osuus on laskenut vuodesta 2011 vuoteen 2016.

Taulukon 8 mukaan Bonnierin osuus kaikki kirjallisuus huomioon ottaen oli vuonna 201135 ja vuonna 201629 prosenttia, kakkosena olevan Otavan osuudet olivat vastaavasti 26 ja 22 prosenttia. Keskisuurten kustantajien (Gummerus, Siltala, Teos, Docendo ja Into) ${ }^{7}$ osuudet vaihtelivat. Vaikka arvostelut keskittyivät voimakkaasti muutamien kustantajien kirjoihin, aineistoon sisältyi teoksia kaikkiaan 30 kustantajalta. Esimerkiksi syksyllä 2016 lähes puolet arvioiduista kaunokirjoista ja reilusti yli puolet tietokirjoista oli muiden kuin kahden suurimman konsernin julkaisemia, joukossa hyvinkin pieniä ja erikoistuneita kustantajia.

Taulukko 8. Kirja-arviot teoksen kustantajan mukaan syys-marraskuussa 2011 ja 2016

\begin{tabular}{|l|cc|cc|cc|cc|}
\hline Kirjallisuudenlaji & \multicolumn{2}{|c|}{ Kaunokirjallisuus } & \multicolumn{2}{|c|}{ Tietokirjallisuus } & \multicolumn{2}{c|}{ Muи kirjallisuus } & \multicolumn{2}{c|}{ Yhteensä } \\
\hline Kustantaja & $\mathbf{2 0 1 1}$ & $\mathbf{2 0 1 6}$ & $\mathbf{2 0 1 1}$ & $\mathbf{2 0 1 6}$ & $\mathbf{2 0 1 1}$ & $\mathbf{2 0 1 6}$ & $\mathbf{2 0 1 1}$ & $\mathbf{2 0 1 6}$ \\
\hline Bonnier Books Finland & 36,0 & 41,9 & 17,4 & 10,5 & 60,0 & 0,0 & 35,4 & 29,1 \\
Otava-konserni & 25,8 & 16,1 & 39,1 & 31,6 & 6,7 & 33,3 & 26,0 & 22,3 \\
Gummerus & 5,6 & 6,5 & 13,0 & 2,6 & 6,7 & 0,0 & 7,1 & 4,9 \\
Siltala & 4,5 & 6,5 & 0,0 & 10,5 & 0,0 & 0,0 & 3,1 & 7,8 \\
Teos & 9,0 & 3,2 & 4,3 & 2,6 & 0,0 & 0,0 & 7,1 & 2,9 \\
Docendo & 0,0 & 0,0 & 0,0 & 15,8 & 0,0 & 0,0 & 0,0 & 5,8 \\
Into & 1,1 & 3,2 & 0,0 & 5,3 & 0,0 & 0,0 & 0,8 & 3,9 \\
Muut kustantajat & 18,0 & $\mathbf{2 2 , 6}$ & $\mathbf{2 6 , 1}$ & $\mathbf{2 1 , 1}$ & $\mathbf{2 6 , 7}$ & $\mathbf{6 6 , 7}$ & $\mathbf{2 0 , 5}$ & $\mathbf{2 3 , 3}$ \\
Yhteensä & $\mathbf{1 0 0 , 0}$ & $\mathbf{1 0 0 , 0}$ & $\mathbf{1 0 0 , 0}$ & $\mathbf{1 0 0 , 0}$ & $\mathbf{1 0 0 , 0}$ & $\mathbf{1 0 0 , 0}$ & $\mathbf{1 0 0 , 0}$ & $\mathbf{1 0 0 , 0}$ \\
\hline Arvioituja kirjoja (N) & $\mathbf{8 9}$ & $\mathbf{6 2}$ & $\mathbf{2 3}$ & $\mathbf{3 8}$ & $\mathbf{1 5}$ & $\mathbf{3}$ & $\mathbf{1 2 7}$ & $\mathbf{1 0 3}$ \\
\hline
\end{tabular}


Kotimaisista kirjailijoista tarkastelujaksolla nousi selvästi esille kaksi ryhmää, yhtäältä sellaiset kirjailijat, jotka muutoinkin ovat valmiiksi paljon julkisuudessa (Jari Tervo, Kari Hotakainen, Tuomas Kyrö, Laila Hirvisaari), ja toisaalta Helsingin Sanomien omaa kirjallisuuspalkintoa tavoittelevat esikoiskirjailijat. Englanninkielisten ja etenkin yhdysvaltalaisten kirjojen vähäinen osuus syksyn 2016 aineistossa on yllätys, sillä vielä syksyllä 2011 ulkomaista kirjallisuutta käsiteltäessä esillä olivat korostetusti yhdysvaltalaiset kirjailijat, kuten Jonathan Franzen, Michael Cunningham, Don DeLillo, Julie Orringer ja Annie Proulx.

Tässä jaksossa tarkastelemme, miten henkilöityminen ilmeni kulttuuriosaston kirjallisuutta käsittelevissä lähtöjutuissa, joita oli kaikkiaan 48. Avausjuttujen tarkastelu on kiinnostavaa, koska se kuvaa osaston sisällä kulttuurin eri alojen painoarvoa. Juttujen lähestymistapa kertoo journalistisesta kulttuurista; journalistisen paradigman vahvistuessa pääjutun valikoituminen perustuu ajankohtaiseen uutistilanteeseen. Merkittävä osa lähtöjutuista oli haastatteluja $(41,5 \%)$ tai feature-juttuja (29,2 \%). Kirja-arvio esiintyi lähtöjuttuna harvemmin (14,6\%), puhumattakaan esseistä tai uutisista, joiden nosto osaston kärjeksi oli satunnaista.

Sanomalehtien sisällöllistä tabloidisaatiota koskevissa tutkimuksissa on yhdeksi viihteellistymisen piirteeksi mainittu juttujen henkilöityminen ja intiimistyminen (Andersson 2013; Saari 2014; Uribe \& Gunter 2004). Ihmisistä ei nosteta esille pelkästään heidän julkista rooliaan ja toimintaansa ammatissa, vaan enenevässä määrin yksityisen elämän asiat, intiimin sfääri. Julkisuuden henkilöinä kirjailijoilta odotetaan julkisia esiintymisiä ja sen myötä toimimista omien teostensa markkinoijina. Saari $(2014,7)$ arvioi, että kirjailijoista kirjoitettaisiin yhä enemmän henkilöjuttuja, mikä kertoisi median kokonaisvaltaisesta henkilöitymisestä. Onko haastattelujen intiimistymisestä viitteitä omassa aineistossamme? Sen selvittämiseksi lähiluimme kulttuuriosaston lähtöjuttuina olevat kirjailijahaastattelut.

Vuonna 2011 Helsingin Sanomien kulttuuriosaston pääjutuista 20 käsitteli kirjallisuutta, ja haastatteluja niistä oli puolet. Haastatelluista suomalaisia olivat Jari Tervo, Mirkka Rekola, Satu Taskinen sekä sivun laajuisessa kiertohaastattelussa kaikki kymmenen lehden vuotuista kirjallisuuspalkintoa tavoitellutta kirjailijaa, joista jokaiselta oli kysytty, miksi kirjoitat, miksi juuri tämän kirjan, miten sijoitut kotimaiseen kirjallisuuteen sekä minkä kirjan viimeksi luit. Lisäksi haastateltiin yhtä ruotsalaista (Lukas Moodysson), yhtä virolaista (Mari Saat) ja neljää yhdysvaltalaista kirjailijaa (Jonathan Franzen, Don DeLillo, Michael Cunningham, Jill Orringer).

Kotimaisten kirjailijoiden haastatteluissa intiimi sfääri oli eniten esillä Jari Tervon haastattelussa. ${ }^{8}$ Jutussa viitattiin julkisuudessa usein esiintyneeseen kirjailijan puolisoon, joka on lööppijulkisuudessa kertonut muun muassa pariskunnan perhe- ja seksielämästä, samoin tuotiin esille perheen 12-vuotias poika, 
joka hänkin jo kirjoittaa. Viitteitä intiimiin oli myös Mirkka Rekolan haastattelussa, ${ }^{9}$ jossa esille tulivat runoilijan lapsuusajan heikko terveys sekä hänen jo varhain kokemansa toiseus: "Silloin ei ollut sukupuolivähemmistöjä, vaan lainrikkojia. Minä erakoiduin". Rekolan puolisoa, runoilija ja kriitikko Mirjam Polkusta ei mainittu.

Lehden oman kirjallisuuspalkinnon voittajan Satu Taskisen haastattelu ${ }^{10}$ oli tehty Wienissä, jossa kirjailija asuu itävaltalaisen puolisonsa kanssa. Haastattelun runkona oli päivällispöytäkeskustelu kirjailijan kanssa, mikä kytki tilanteen palkitun romaanin, Täydellisen paistin, tematiikkaan. Haastattelussa kuvailtiin kirjailijan rentoa kotiolemusta, johon haastattelun tehnyt toimittaja oli tutustunut ennen päivällispöytään siirtymistä. Keskustelu polveili Taskisen elämänvaiheiden, teoksen kirjoittamisen sekä teoksen sisällön kuvailun välillä. Mitään intiimiä kirjailijasta ei kerrottu, jos ei oteta huomioon mainintaa, että hän käy torstaisin Wienissä yleisessä saunassa.

Vuonna 2016 kulttuuriosaston pääjutuista 28 käsitteli kirjallisuutta, ja haastatteluja niistä oli kymmenen. Suomalaisia haastateltuja olivat kirjailijoista Jari Tervo, Markus Leikola, Kari Hukkila ja Hanna Weselius, jota haastateltiin kolmen kuukauden aikana kahdesti: ensin ennakkoon lehden oman kirjallisuuspalkinnon tavoittelijana ${ }^{11}$ ja sitten sen voittajana. ${ }^{12}$ Haastatelluista Jaana Kapari-Jatta on kääntäjä. Vuoden 2011 tapaan Helsingin Sanomat esitteli koko sivun kiertohaastattelussa kaikki kymmenen lehden kirjallisuuspalkinnon tavoittelijaa, joilta tällä kertaa kysyttiin, miksi kirjoitat, miksi juuri tämän kirjan ja miten sijoitut kotimaiseen kirjallisuuteen. Vastauksille oli tilaa huomattavasti enemmän kuin vuoden 2011 kyselyssä. Ulkomaisista kirjailijoista haastateltiin yhtä yhdysvaltalaista (Emma Cline), yhtä venäläistä (Guzel Jahina) sekä yhtä yhdysvaltalais-italialaista kirjailijaa (Donna Leon). Kiinnostavia piirteitä ovat haastattelujen painopisteen siirtyminen vahvasti kotimaisiin kirjailijoihin sekä Hanna Weseliuksen saama suuri huomio, ensimmäisessä haastattelussa runsaat kolme ja toisessa kaksi täyttä sivua.

Kirjailijahaastattelujen yhtenäinen piirre oli nyt vuoropuhelu haastattelijan ja kirjailijan välillä siten, että keskustellaan kirjailijan työstä, teoksesta tai laajemmin hänen tuotannostaan ja sen taustoista. Oireellinen on toimittaja Aino Frilanderin kommentti Emma Clinen haastattelussa: "Hän haluaa pitää keskustelun tiukasti kirjassa" ${ }^{13}$ Haastattelujen toistuvia yleisiä teemoja olivat ajankohtaiset maahanmuutto, pakolaisuus ja vähemmistöjen asema (Tervon, Leikolan, Hukkilan ja Jahinan haastattelut; lisäksi ne olivat vahvasti esillä 25.9. kulttuuriosaston avanneessa Sofi Oksasen esseessä ${ }^{14}$ ).

Syksyn 2016 kirjailijahaastatteluissa intiimin sfääriin kuuluvat seikat suorastaan loistivat poissaolollaan; poikkeuksina olivat vain Jari Tervon haastattelun $^{15}$ maininta hänen Matriarkka-teoksen kirjoittamisen aikana saamistaan rytmihäiriöistä ja niiden hoitamisesta sekä Jaana Kapari-Jatan haastattelun ${ }^{16}$ maininta hänen ankarista selkäkivuistaan juuri ennen Potter-käännöksen valmistumista. Jonkin verran enemmän intiimiä elämää sisältyi feature-juttuun 
Roald Dahlista ${ }^{17}$ sekä Bruce Springsteenin elämäkerran arvioon..$^{18}$ Helsingin Sanomain kirjallisuuspalkinnon edellisvuotinen voittaja Saara Turunen tarkasteli esseessään, ${ }^{19}$ miten palkinto yhdessä yössä muutti hänen julkista rooliaan, mutta intiimin elämän tasolle hän ei pohdiskeluaan vienyt.

Kulttuuriosaston avauksena olevissa kirjallisuusjutuissa tabloidisaatiohypoteesin oletukset sisällöllisestä keventymisestä, siirtymisestä julkisesta roolista yksityiseen, eivät toteutuneet. Haastattelut noudattelivat molempina vuosina samaa toimittamisen tapaa. Haastateltava asemoitiin aluksi miljööseen, jossa haastattelu tapahtuu. Sen jälkeen luonnehdittiin muutamin piirtein hänen persoonallisuuttaan. Pääasiassa keskityttiin haastatellun julkiseen rooliin kirjailijana, hänen teoksiinsa sekä niiden taustoihin. Tämä näkyi erityisesti ulkomaisten kirjailijoiden haastatteluissa. Privaattiin ja intiimiin liittyviä mainintoja löytyi aavistuksen verran enemmän vuoden 2011 pääjuttuina olleista haastatteluista. Haastattelujen määrän pysyessä vertailuvuosina kappalemääräisesti samana, vaikka kirjallisuusaiheisten pääjuttujen kokonaismäärä nousi merkittävästi, juttujen henkilöityminen heikentyi, ja se on vastoin tabloidisaatiohypoteesin oletusta.

\section{Muuttiko tabloidi kirjallisuusjournalismia?}

Olemme tässä artikkelissa tarkastelleet empiirisen aineiston avulla, muuttuiko Helsingin Sanomien kirjallisuutta käsittelevä journalismi lehden siirryttyä tabloidikokoon. Tabloidisaatiohypoteesin mukaisesti odotimme muutosten ilmenevän journalismin muodoissa, sisällöllisissä painotuksissa ja puhuttelutavoissa.

Muodon tasolla kirjallisuusjournalismi oli Helsingin Sanomissa visualisoitunut, ja se ilmeni kuvien määrän kasvuna, mutta vastoin odotuksia tekstit eivät olleet lyhentyneet, vaan päinvastoin merkittävästi pidentyneet. Odotuksen mukaisesti kirjallisuusjournalismi oli entistä selvemmin toimituksen itse tuottamaa, joskin kaunokirjallisuuden arvioinnin lehti oli siirtänyt aiempaa selvemmin freelancereille. Sisällöllisten painotusten tasolla arvioiden suhteellinen osuus vastoin odotusta hieman kasvoi, mutta odotusten mukaisesti kauno- ja lastenkirjallisuuden arviot vähenivät. Kaunokirjojen arvioissa eniten näkyvyyttä saivat odotuksen mukaisesti kotimaiset aikalaisromaanit, käännöskirjojen arviot vähenivät. Odotettua oli runokokoelmien arvioinnin väheneminen. Varsinaisen genrekirjallisuuden osuus arvioista jäi odotettua vähäisemmäksi. Puhuttelutavan tasolla tabloidisaation merkki oli näyttävien kirjailijahaastattelujen keskeinen osa osaston lähtöjutuista. Haastattelujen intiimistymisestä löysimme kuitenkin vain satunnaisia merkkejä.

Tuloksemme puhuvat kirjallisuusjuttujen journalistisoitumisesta. Journalistisen paradigman vahvistuminen näkyy journalistisen genrepaletin monipuolisena käyttönä. Uutisten, haastattelujen, feature-juttujen, arvioiden, kolumnien ja erilaisten suositusten julkaiseminen ilmentää lehtien tarvetta etsiä lukijays- 
Epäsuhta suurin otsikoin ja näyttävin kuvin käsiteltyjen

yksittäisten kirjailijoiden ja teosten sekä kokonaan

arvioimatta jäävän suuren massan välillä oli molempina

vuosina havaittavissa.

tävällisiä journalismin keinoja. Tietokirjallisuuden käsittelyssä syksyllä 2016 yleistyi tapa korvata perinteinen arvio kirjan keskeistä sisältöä avaavalla, kertovalla feature-jutulla. Arvioiden suhteellisen osuuden hienoinen lisäys samoin kuin pohtivan esseen paluu ovat vastatendenssi journalistisoitumiselle. Tabloidisaatio ei ole johdonmukaista, vaan se tuottaa ristiriitaisia ilmenemismuotoja.

Toisaalta tulokset kertovat toimituksen kontrollin kasvusta, mikä on tabloidisaatiohypoteesin mukaista. Vuodesta 2011 vuoteen 2016 tietokirjallisuuden arvioinnissa tapahtui näkyvä siirtymä asiantuntijoilta lehden omille toimittajille, ja vaikka kaunokirjallisuudessa freelancereiden osuus kasvoi, kritiikkitilauksissa päätösvalta on toimituksella. Harvoja poikkeuksia lukuun ottamatta myös esseet olivat kulttuuritoimituksen toimittajien omaa tuotosta.

Oletus kirjailijan kuvan noususta tekstiä tärkeämmäksi saa tuloksistamme tukea, sillä enää vain harva kirja-arvio ilmestyi syksyllä 2016 ilman kuvaa, ja nimenomaan lähtöjuttuina julkaistujen haastattelujen yhteydessä kuvien koko kasvoi. Journalistisoitumista on myös tarjotun näkyvyyden valikoivuus, mitä käsiteltyjen kirjojen määrän väheneminen korostaaa. Epäsuhta suurin otsikoin ja näyttävin kuvin käsiteltyjen yksittäisten kirjailijoiden ja teosten sekä kokonaan arvioimatta jäävän suuren massan välillä oli molempina vuosina havaittavissa.

Sisältöjen popularisoitumiselle tutkimuksemme antaa vain osittain tukea. Muutos tabloidiin ei ilmennyt arvostelupalstoilla genre- tai populaarikirjallisuuden näkyvänä osuutena, sillä lukijoiden erityisesti suosimista genreistä rikoskirjallisuus ja historialliset romaanit olivat sekä ennen tabloidia että muutoksen jälkeen arvioissa esillä molemmat noin kuudenneksen osuuksilla. Sen sijaan tietokirja-arvioissa havaittiin pyrkimys puhutella tavallista laajempaa yleisöä ja ylittää taiteenalojen välisiä raja-aitoja. 
Märällisessä näkyvyydessä kirjallisuusjournalismia ja -kritiikkiä koskevalle kriisipuheelle ei löytynyt katetta. Helsingin Sanomissa kulttuuriosasto supistui 2000-luvun alkuvuosina. Se on 2010-luvulla kääntynyt jälleen lievään kasvuun käytössä olevalla palstatilalla mitattuna, mutta juttujen kappalemäärä on selvästi vähentynyt. Osaston sisällä kirjallisuus ei ole joutunut antamaan periksi muille taiteille, ja lähtöjutuissa sen asema on suhteellisesti vahvistunut. Kritiikin asema kirjallisuusjuttujen kokonaisuudessa ei ole heikentynyt, ja arviot ovat tarkastelujaksolla selvästi pidentyneet.

Olemme tarkastelleet kirjallisuusjournalismin muutoksia tabloidisaation näkökulmasta. Tabloidiformaattiin siirtyminen ilmentää sanomalehtien kilpailuympäristön muutoksia ja painetta kasvavaan lukijalähtöisyyteen. Samanaikaisesti sen rinnalla on edennyt sanomalehtien digitalisaatio. Kuten pienempi sivukoko, myös pyrkimys julkaista "verkko edellä", eli tehdä sisältöä ensisijaisesti digitaaliseen levitykseen, vaikuttaa journalismin muotoon, sisällöllisiin painotuksiin ja puhuttelutapaan. Olemme toisaalla esittäneet, että digitalisaation vaikutus on samansuuntainen kuin tabloidisaation: verkko mahdollistaa aiempaa pidempien juttujen julkaisemisen sekä suosii henkilöön keskittyviä ja tarinallisia juttutyyppejä (Hellman \& Ruohonen 2019, 231). Digitilaajille tarkoitetut laajat erikoisartikkelit siirtyvät pääosin myös painettuun lehteen muovaten sen ilmettä ja kasvattaen juttujen keskimittaa. ${ }^{20}$

Digitalisaatio on vaikuttanut kritiikin foorumeihin ja asemaan muutenkin perustavalla tavalla. Samalla kun perinteinen media on kadottanut yleisöään, uudet digitaaliset media-alustat ovat mahdollistaneet sen, että kuka tahansa voi nostaa esiin kulttuurituotteita ja esittää niistä mielipiteensä - että "kaikki ovat kriitikoita" (McDonald 2007). Sanomalehtien kirjallisuuskritiikin ovat 2010-luvulla haastaneet sekä kirjallisuusblogit että sosiaalisen median alustoilla kukkiva lukijoiden itse kirjoittama vertaiskritiikki. Suosituimmilla blogeilla voi olla tuhansia aktiivisia seuraajia, ja bloggaajien joukossa on myös päteviä ammattikriitikoita, jotka nojaavat institutionaalisen kritiikin konventioihin (Ruohonen 2018a).

Amatöörien "vernakulaarinen" eli epävirallinen ja epäinstitutionaalinen kritiikki puolestaan on havaittu korostuneen henkilö- ja omakohtaiseksi (Jaakkola 2019; Juntunen 2015). Siten se edustaa aivan erilaista diskurssia kuin ammattimainen kritiikki, eikä suosiostaan huolimatta voi korvata sitä. Kirjallisuusinstituution näkökulmasta kirjallisuusblogit voivat sen sijaan täydentää ja jopa korvata sanomalehtikritiikin väheneviä foorumeita. Vaikka kustantajat lainaavat nykyään jo rutiininomaisesti blogien arvioita kirjojensa liepeisiin, sanomalehtikritiikillä on yhä suuri painoarvo päätettäessä, mitkä teokset nousevat kirjallisuuden kaanoniin ja kilpailemaan merkittävimmistä kirjallisuuspalkinnoista, ja ketkä kirjailijat saavat apurahoja ja muita tunnustuksia (Ruohonen \& Hellman 2020).

Mistä asiantuntijakriitikoiden käytön väheneminen viime kädessä kertoo? Yhtäältä oletamme sen olevan seurausta samoista taloudellisista seikoista, jotka 
ovat osaltaan suosineet myös tabloidisaatiota. Kun toimituksia ja avustajabudjetteja on levikkien laskiessa pienennetty, aikaisemmin tietyn kirjan arvioijaksi kutsuttu asiantuntija, vaikkapa kirjallisuustieteen professori, koetaankin uudessa tilanteessa helposti liian kalliiksi eikä aina lukijaystävälliseksikään ratkaisuksi. Oma toimittaja, ja jopa freelancer, on paitsi joustavampi myös edullisempi. Myös yliopiston ja Helsingin Sanomien kulttuuritoimituksen takavuosina tiiviiksi kuvattu yhteys (ks. Tarkka 2018) on ohentunut, eikä yliopistojen rahoitusmallikaan suosi tutkijoiden kirjoittelua sanomalehdissä.

Vaikka katsoimme kolmen kuukauden mittaisen tutkimusjakson edustavan hyvin tutkitun lehden kirjallisuusjournalismia, keskittyminen nimenomaan kirjasyksyyn saattaa osin selittää tuloksia. Kirjamessut sekä keskeisten kirjallisuuspalkintojen myöntäminen loppusyksystä saattavat korostaa kotimaisen ja ylipäänsä luetuimman kirjallisuuden osuutta kulttuurisivuilla. On mahdollista, että keväällä kirjallisuutta käsitellään vähemmän kuin syksyllä mutta esille nousee enemmän käännöskirjoja ja kaupallisesti vähemmän merkittäviä teoksia, esimerkiksi runoutta.

Jatkossa näkökulmia onkin syytä avartaa. Tulevaisuudessa sanomalehtien kirjallisuusjournalismin tutkimusta tulisi laajentaa esimerkiksi ajallisesti eri vuodenaikoihin sekä useampiin, eri alueilla ilmestyviin päivälehtiin ja myös niiden verkkosivuihin, jolloin saataisiin tutkittua tietoa siitä, eroaako verkon kirjallisuuskritiikki painetusta. Lisäksi kritiikin ja kirjallisuusjournalismin sisällön muutoksia tulisi tutkia laadullisesti paneutumalla tekstien rakenteisiin ja argumentointitapoihin. Niiden tarkastelu antaisi tietoa siitä, miten kirjallisuuskritiikki ja -journalismi eri aikoina ja eri välineissä puhuttelevat yleisöjään.

\section{Viitteet}

1 Tavanomaisen kulttuuriosaston paikalla ilmestyneet kirjamessuliitteet ilmestyivät keskiviikkona 26.10.2011 ja keskiviikkona 26.10.2016.

2 Luokitusperiaatteita ja luokitusten reliabiliteettia olemme selostaneet tarkemmin toisessa yhteydessä (Hellman \& Ruohonen 2019, 220-24).

3 Osastojaon kehityksestä suomalaisissa lehdissä ks. Pulkkinen 2008, 99-116.

4 Sunnuntainumeroissa kulttuuri vakiintui oman niskansa avaukseksi vasta lokakuussa 2016, siihen asti sen paikka oli sunnuntaisivujen jälkeen.

5 Vuoden 2019 alusta lähtien Bonnier Kir- jat Suomi tunnetaan jälleen nimellä Werner Söderström Osakeyhtiö. Sen sisällä toimivat WSOY, Tammi, Johnny Kniga, Kosmos ja Readme.fi sekä elokuusta 2019 alkaen myös Bazar Kustannus.

6 Otava-konserniin kuuluvat muun muassa Kustannusosakeyhtiö Otava, Like Kustannus Oy, Kustannusyhtiö Nemo ja Kustannusyhtiö Moreeni. Vuoden 2020 alussa Otava osti perinteikkään Kariston kustannustoiminnan.

7 Toisen perinteisen kustannusliikkeen, Gummeruksen omistajaksi tuli syksyllä 2019 monikansallinen, erityisesti digitaalista kirjallisuutta julkaiseva Storytel. Pienemmistä 
kustantamoista osuuskunta CrimeTimen

tuotemerkillä rikoskirjallisuutta julkaissut

Pulitzer Oy siirtyi loppuvuodesta 2018

Docendolle.

8 Ks. Katri Kallionpää, "Sielulla ei ole sukupuolta", Helsingin Sanomat 2.9.2011, s. C1.

9 Ks. Noora Mattila, Mirkka Rekolan pitkä ja kummallinen matka, Helsingin Sanomat 25.9.2011, S. C1.

10 Ks. Hanna Syrjälä, Neljän vuoden haudutus, Helsingin Sanomat 16.11.2011, s. C1.

11 Ks. Sanna Kangasniemi, Naisen ruumis, aina tiellä, Helsingin Sanomat 3.9.2016, s.

$\mathrm{C}_{1}-\mathrm{C}_{4}$.

12 Ks. Riitta Koivuranta, Kuvat eivät enää riittäneet, Helsingin Sanomat 17.11.2016, S. $\mathrm{B} 1-\mathrm{B} 2$.

13 Ks. Aino Frilander, Emma Cline - kesän varjot, Helsingin Sanomat 21.9.2016, s. B1-B2.

14 Ks. Sofi Oksanen, Nuoret miehet pakenevat sotaa, Helsingin Sanomat 25.9.2016, s. $\mathrm{C}_{14}-\mathrm{C}_{15}$.
15 Ks. Hanna Mahlamäki, Murhatun kansan ääni, Helsingin Sanomat 10.9.2016, s $\mathrm{C}_{1}-\mathrm{C}_{3}$.

16 Ks. Suvi Ahola, Hän tuntee aikuisen Harry Potterin, Helsingin Sanomat 22.10.2016, s. $\mathrm{C}_{1}-\mathrm{C}_{3}$.

17 Ks. Riikka Forsström, Roald Dahl ja lapsuuden julma maailma, Helsingin Sanomat 13.9.2016, S. B1-B2.

18 Ks. Vesa Sirén, Bruce Springsteensyntynyt masentumaan, Helsingin Sanomat 27.9.2016, s. B1-B2.

19 Ks. Saara Turunen, Kaikki oli muuttunut yhdessä yössä, Helsingin Sanomat 16.11.2016, S. B1-B2.

20 Näin tabloidisaation ja digitalisaation yhteyttä selittävät myös lehden tekijät. Ks. esim. Vesa Sirén, Tabloid tuli, mikä muuttui? Tutkijat yllättyivät, kun kulttuurisivujen määrä kasvoi Helsingin Sanomissa, Helsingin Sanomat 19.1.2020, s. C1-C3.

\section{Kirjallisuus}

Andersson, Ulrika 2013. From Broadsheet to Tabloid: Content Changes in Swedish Newspapers in the Light of a Shrunken Size. Observatorio (OBS*) Journal 7(4), 1-21.

Djupsund, Göran \& Tom Carlson 1998. Trivial Stories and Fancy Pictures? Tabloidization Tendencies in Finnish and Swedish Regional and National Newspapers 1982-1997. Nordicom Review 19(1), 101-13.

Eskola, Katarina 1990. Lukijoiden kirjallisuus - Sinuhesta Sonja O:hon. Helsinki: Tammi.

Esser, Frank 1999. "Tabloidization" of News: A Comparative Analysis of Anglo-American and German Press Journalism. European Journal of Communication 14(3), 291-324.

Heikkilä, Riie, Tina Laurila \& Semi Purhonen 2018. The Crisis of Cultural Journalism Revisited The Space and Place of Culture in Quality European Newspapers from 1960 to 2010. European Journal of Cultural Studies 21(6), 669-86.

Hellman, Heikki \& Maarit Jaakkola 2009. Kulttuuritoimitus uutisopissa: Kulttuurijournalismin muutos Helsingin Sanomissa 1978-2008. Media \& viestintä 32(4-5), 24-42.

Hellman, Heikki \& Voitto Ruohonen 2019. Kirjallisuus kohtaa tabloidisaation: Pienempi sivukoko ja Helsingin Sanomien kulttuurijournalismin muutos. Media \& viestintä 42(4), 213-34.

Honkonen, Juho 2013. Juttujen määrä alamäessä. Media \& viestintä 36(1), 47-51.

Hurri, Merja 1993. Kulttuuriosasto: Symboliset taistelut, sukupolvikonflikti ja sananvapaus viiden pääkaupunkilehden kulttuuritoimituksissa 1945-1980. Acta Universitatis Tamperensis A 389. Tampere: Tampereen yliopisto. 
Jaakkola, Maarit 2013. Taidekritiikin muutos suomalaisissa sanomalehdissä 1978-2008. Kulttuurintutkimus 30(4), 31-45.

Jaakkola, Maarit 2015a. Outsourcing Views, Developing News. Changes in Art Criticism in Finnish Dailies. Journalism Studies 16(3), 383-402.

Jaakkola, Maarit 2015b. The Contested Autonomy of Arts and Journalism: Change and Continuity in the Dual Professionalism of Cultural Journalism. Acta Universitatis Tamperensis 2072. Tampere: Tampere University Press.

Jaakkola, Maarit 2019. From Re-viewers to Me-viewers: The \#Bookstagram Review Sphere on Instagram and the Uses of the Perceived Platform and Cenre Affordances. Interactions: Studies in Communication and Culture 10(1\&2), 91-110.

Juntunen, Heli 2015. Kirjallisuuskritiikkien ja kirjablogien kirjallisuuspuhe: Kari Hotakaisen teosten Juoksuhaudantie, Ihmisen osa, Jumalan sana ja Luonnon laki vastaanotto ammattikritiikeissä ja kirjablogeissa. Kirjallisuuden pro gradu. Itä-Suomen yliopisto.

Kantokorpi, Mervi 2013. Kritiikki ja kirjallisuuspalkinnot osana kirjallista julkisuutta. Teoksessa Suomen nykykirjallisuus 2: Kirjallinen elämä ja yhteiskunta. Toim. Mika Hallila, Yrjö Hosiaisluoma, Sanna Karkulehto, Leena Kirstinä \& Jussi Ojajärvi. Helsinki: Suomalaisen Kirjallisuuden Seura, 194-207.

Korhonen, Kuisma 2012. Kirjallisuuskritiikki: Tekstejä teksteistä. Teoksessa Taidekritiikin perusteet. Toim. Martta Heikkilä. Helsinki: Caudeamus, 55-83.

Linko, Maaria 2016. Tietokirjallisuuden näkyvyys selailukulttuurissa. Helsinki: Suomen tietokirjailijat.

McDonald, Ronan 2007. Death of the Critic. Lontoo: Continuum.

McLachlan, Shelley \& Peter Colding 2000. Tabloidization in the British Press: A Quantitative Investigation into Changes in British Newspapers, 1952-1997. Teoksessa Tabloid Tales: Clobal Debates over Media Standards. Eds. Colin Sparks \& John Tulloch. Lanham, Maryland: Rowman \& Littlefield Publishers, 75-89.

Pulkkinen, Hannu 2008. Uutisten arkkitehtuuri: Sanomalehden ulkoasun rakenteiden järjestys ja jousto. Jyväskylä studies in humanities 88. Jyväskylä: Jyväskylän yliopisto.

Purhonen, Semi, Jukka Cronow, Riie Heikkilä, Nina Kahma, Keijo Rahkonen \& Arho Toikka 2014. Suomalainen maku: Kulttuuripääoma, kulutus ja elämäntyylien sosiaalinen eriytyminen. Helsinki: Caudeamus.

Purhonen, Semi, Riie Heikkilä, Irmak Karademir Hazır, Tina Lauronen, Carlos ]. Fernández Rodríguez \& Jukka Gronow 2019. Enter Culture, Exit Arts? The Transformation of Cultural Hierarchies in European Newspaper Culture Sections, 1960-2010. Lontoo: Routledge.

Reunanen, Esa 2013. Varovasti tabloidimaisemmaksi. Teoksessa Pienempään kuosiin: Helsingin Sanomien ja Satakunnan Kansan tabloidi-uudistus sisällön, tekijöiden, lukijoiden ja ilmoittajien näkökulmasta. Toim. Esa Reunanen. Tampere: COMET, Tampereen yliopisto, 12-41.

Reunanen, Esa, Kari Koljonen, Maarit Mäkinen \& Susanna Vehmas 2013. Tabloidin lumo ja pelko. Teoksessa Pienempään kuosiin: Helsingin Sanomien ja Satakunnan Kansan tabloidiuudistus sisällön, tekijöiden, lukijoiden ja ilmoittajien näkökulmasta. Toim. Esa Reunanen. Tampere: COMET, Tampereen yliopisto, $71-75$.

Ruohonen, Voitto 2018a. Kapitalismi, julkisuus, kirjallisuus ja Web 2.0. Teoksessa Kirjallisuus nykykapitalismissa: Suomalaisen kirjallisuuden ja kulttuurin näkökulma. Toim. Jussi Ojajärvi, Erkki Sevänen \& Liisa Steinby. Suomalaisen Kirjallisuuden Seuran Toimituksia 1444. Helsinki: SKS, 144-174.

Ruohonen, Voitto 2018b. Kulttuurijournalismin muodonmuutos: Kirjallisuus 2010-luvun alun Helsingin Sanomien kulttuuriosastossa. Teoksessa Kirjallisuus nykykapitalismissa: Suomalaisen kirjallisuuden ja kulttuurin näkökulma. Toim. Jussi Ojajärvi, Erkki Sevänen \& Liisa Steinby. Suomalaisen Kirjallisuuden Seuran Toimituksia 1444. Helsinki: SKS, 175-98. 
Ruohonen, Voitto \& Heikki Hellman 2020. Kritiikki journalismin ja digitalisaation puristuksessa: Journalistit kulttuurisina välittäjinä uudessa mediaympäristössä. WiderScreen 21(1).

Saari, Tiina 2014. Uutisia! Arvioita? Kirjasta ja sen tekijästä kirjoitetut journalistiset jutut Helsingin Sanomissa ja Satakunnan Kansassa syksyllä 2012. Journalistiikan pro gradu. Jyväskylän yliopisto, viestinnän laitos.

Sevänen, Erkki 2018. Modernin taideautonomian synty ja sen kohtalo nykykapitalismissa. Teoksessa Kirjallisuus nykykapitalismissa: Suomalaisen kirjallisuuden ja kulttuurin näkökulma. Toim. Jussi Ojajärvi, Erkki Sevänen \& Liisa Steinby. Suomalaisen Kirjallisuuden Seuran Toimituksia 1444. Helsinki: SKS, 99-143.

Sternvik, Josefine 2007. I krympt kostym: Morgontidningarnas formatförändring och dess konsekvenser. Göteborg: Göteborgs universitet.

Tarkka, Pekka 2018. Onnen Pekka. Helsinki: Otava.

Uribe, Rodrigo \& Barrie Gunter 2004. The Tabloidization of British Tabloids. European Journal of Communication 19(3), 387-402.

Verboord, Marc \& Susanne Janssen 2015. Arts Journalism and its Packaging in France, Germany, The Netherlands and the United States, 1955-2005. Journalism Practice 9(6), 829-52. 